\title{
Graduate Student Literature Review: Systemic mediators of inflammation during mastitis and the search for mechanisms underlying impaired lactation*
}

E. M. Shangraw† $\odot$ and T. B. McFadden $¥ \odot$

Division of Animal Sciences, University of Missouri, Columbia 65211

\section{INTRODUCTION}

The negative effect of mastitis on lactation is well established, yet the mechanisms causing reduced milk production in the afflicted dairy cow are not. As one of the major inflammatory diseases in the dairy industry, mastitis has rightly received considerable research interest for decades. However, the focus on distinct, pathologic effects in mastitic glands has largely overlooked systemic effects on noninflamed mammary glands. This is particularly evident in the severe, acute response to the potent inflammatory mediator, lipopolysaccharide (LPS). Whereas secretory cell death, impaired tight junctions, and migration of leukocytes are locally restricted to an inflamed, LPS-challenged gland, changes in milk yield and milk components may be detectable in all mammary glands. Further, these differences extend to the mammary transcriptome. Notably, few transcriptomic studies have been designed to test for effects of systemic mediators of inflammation on gene expression. Relevant changes in the noninflamed mammary gland, identified through biochemical analyses and transcriptional studies, warrant further research. Current evidence suggests proinflammatory cytokines play a role in regulating lactose synthesis, but additional candidates and mechanisms continue to be identified. Ultimately, understanding how systemic mediators of inflammation affect mammary function may lead to the development of interventions that enable more efficient milk production without sacrificing the benefits of inflammation.

Key words: endotoxin, hypogalactia

Received May 23, 2021.

Accepted November 1, 2021.

*Submitted to the 2022 ADSA Foundation Graduate Student Literature Review Competition (Production, MS) on November 12, 2021.

†Corresponding author: emsyzf@umsystem.edu

$\ddagger$ Advisor (mcfaddent@missouri.edu)
Mastitis remains a prevalent and costly disease that affects the dairy industry. In the United States alone, mastitis is estimated to cost producers over $\$ 600$ million per year (Hogeveen et al., 2019), of which 35 to $60 \%$ of lost revenue is due to impaired milk production (Aghamohammadi et al., 2018; Hogeveen et al., 2019). Because each quarter in the udder is a separate mammary gland, lower milk yields and poorer quality milk are generally attributed to quarters with active cases of mastitis (Hoeben et al., 2000; Burvenich et al., 2003). However, physical independence does not equal functional independence because milk production can be reduced in all glands by systemic mediators of inflammation during clinical mastitis (Shuster et al., 1991b; Mitterhuemer et al., 2010). Despite decades of research, the mechanisms controlling mammary function during clinical mastitis remain unclear, particularly in clinically healthy glands exposed to systemic mediators of inflammation.

\section{OVERVIEW OF MAMMARY PHYSIOLOGY}

The bovine udder is composed of 4 anatomically distinct glands. Each mammary gland develops from a separate mammary bud during embryonic development. In the cow, the parenchymal tissue of the left and right udder halves is separated by the median suspensory ligament. The division between fore and rear quarters is less apparent but demonstrable because milk is not shared between quarters. Consequently, each gland can function individually. However, it is typical for all quarters to respond similarly to an external stimulus, such as temperature, or to an internal stimulus carried in blood. Thus, mammary function is determined by both local and systemic factors (Turner, 1934).

\section{Regulation of Lactation}

Galactopoiesis, defined here as maintenance of lactation, is controlled by both local factors originating within the mammary gland and systemic factors acting 
on the glands (Akers, 2002). A classic example of local control over galactopoiesis is frequency of milk removal, in which only glands subjected to the treatment respond. Compared with standard twice-daily milkings, once-daily milking reduces milk yields and secretion rates (Stelwagen and Knight, 1997), whereas additional milkings increase milk production (Wall and McFadden, 2007). As such, milk removal reinforces galactopoiesis for individual glands. In contrast, introducing a substance into the mammary gland via the teat can induce local antigalactopoietic effects. Some substances, such as $\mathrm{Na}^{+}$or $\mathrm{K}^{+}$, may affect milk production only in the treated gland (Stelwagen et al., 1999), whereas foreign pathogen-derived substances (e.g., endotoxins or peptidoglycan) commonly trigger innate immune responses. An immune response may begin as a local response but can rapidly develop into a systemic response, wherein all quarters are affected by systemic factors.

Similar to local factors, systemic factors may enhance or hinder lactational performance. Circulating galactopoietic hormones, such as prolactin and growth hormone, can maintain or increase milk yields. Current evidence suggests that these hormones have direct effects on mammary epithelial cells (MEC), increasing their proliferation and inducing the transcription of $\mathrm{CN}$ and $\alpha$-LA (Lacasse et al., 2016; McCoard et al., 2016). When these galactopoietic signals decline or are opposed by inhibitors, the mammary gland may transition to involution. Involution is characterized by morphological and metabolic changes in the alveoli and MEC. In nonruminants, involution consists of the following 2 phases: a reversible phase during which tight junctions between MEC weaken as macrophages arrive to promote an inflammatory environment, and an irreversible phase in which MEC commit to apoptosis and the gland is completely remodeled to a nonlactating state (Hughes et al., 2012). In dairy cows, which are typically pregnant during lactation, involution is less drastic; compromised junctions and inflammation develop, but apoptosis is moderated by proliferative signals, ensuring a degree of cell turnover and retention that allows unmilked quarters to resume lactating up to $28 \mathrm{~d}$ after milking has ceased (Singh et al., 2015).

\section{Mammary Defense}

As an exocrine gland, the mammary gland is exposed to the external environment. Physical barriers in the teat provide the primary defense against infection. When this defense fails, an array of humoral and cellular defenses stems the multiplication of pathogens and enables their destruction.

Healthy mammary glands are surveilled by a dynamic population of leukocytes. Though the proportion of each cell type fluctuates with stage of lactation and health status, milk from healthy glands contains mostly macrophages (20-50\%) and lymphocytes (20-60\%), followed by PMN (15-30\%; Merle et al., 2007; Schwarz et al., 2011). Macrophages and PMN are phagocytic cells that respond to pathogens and noxious stimuli via secretion of cytokines and chemokines. Pleiotropic cytokines promote or inhibit inflammation by activating or inhibiting various intracellular pathways, whereas chemokines, a subset of cytokines, recruit circulating leukocytes to the site of the pathogen or stimulus (Bannerman, 2009). The first leukocytes to be recruited are mainly PMN, which, when activated by proinflammatory cytokines, release oxidizing agents and cytotoxic enzymes (Burvenich et al., 2003). Once the pathogen is eliminated, macrophages clear damaged and dead cells and release anti-inflammatory cytokines to restore homeostasis (Porcheray et al., 2005; Aitken et al., 2011).

Mammary epithelial and stromal cells contribute to mammary defense alongside resident leukocytes. Cultured MEC express pathogen recognition receptors and produce cytokines when exposed to bacterial challenges (Ibeagha-Awemu et al., 2008; Günther et al., 2011). Stromal fibroblasts and endothelial cells can further influence the inflammatory response by regulating MEC function and altering the initiation, development, and resolution of inflammation (Ryman et al., 2015; Chen et al., 2016). Thus, mammary tissue can increase recruitment of leukocytes to the affected gland and respond to inflammatory signals.

\section{OVERVIEW OF MASTITIS}

Mastitis is defined as inflammation of the mammary gland and is predominantly caused by an intramammary infection. Due to the anatomy of the udder, the causative mastitis pathogen is typically isolated only from infected glands. Detection of the pathogen by host recognition of its pathogen-associated molecular patterns triggers the recruitment of PMN, which causes the milk SCC to rise. Ideally, the mammary gland clears the pathogens without lasting effects. However, if the gland is exposed to excessive numbers of pathogens or the immune system is compromised, the pathogens can multiply more rapidly and increase the risk of more severe signs of disease (Burvenich et al., 2003).

Notably, different mastitis pathogens cause different responses in terms of severity and resolution. An analysis of mastitis incidence on 2 commercial farms found that gram-negative coliforms, such as Escherichia coli and Klebsiella species, provoked greater acute drops in milk yield than more persistent infections caused by gram-positive bacteria, such as Staphylococcus aureus (Gröhn et al., 2004). Studies on experimental infections 
with $E$. coli or $S$. aureus provide greater insight into this difference in severity. For example, in one study, milk yields were measured before and $24 \mathrm{~h}$ after a bacterial challenge. Yields were reduced by $84 \%$ during $E$. coli infections compared with $30 \%$ in $S$. aureus infections (Petzl et al., 2008). This difference can mainly be attributed to the presence of LPS, a major structural component of the outer membrane of gram-negative bacteria. Importantly, LPS itself may not be cytotoxic; rather, the host response to the endotoxin determines the downstream effects.

\section{Action of LPS}

Each LPS molecule contains a hydrophobic lipid A moiety, a core region of oligosaccharides, and a highly variable $\mathrm{O}$-antigen region of repeating polysaccharide units (Rietschel et al., 1994). The lipid A moiety of bioactive LPS binds to TLR4 (toll-like receptor 4), an LPS-specific pattern recognition receptor present on leukocytes and epithelial cells (Ibeagha-Awemu et al., 2008). Activation of TLR4 by LPS is catalyzed by the following 3 cofactors: LBP (LPS-binding protein), MD2 (myeloid differentiation-2), and CD14 (cluster of differentiation-14; (Verstrepen et al., 2008). Once activated, the signaling cascade induces the activation of NFKB (nuclear factor- $\kappa \mathrm{B}$ ) transcription factors (Verstrepen et al., 2008).

The highly conserved family of NFKB transcription factors regulate inflammatory and stress-related genes. Inhibitor of $\kappa \mathrm{B}$ (IKB) proteins normally maintain NFKB in an inactive state outside the nucleus. When

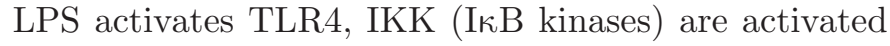
and phosphorylate IKB to release NFKB (Verstrepen et al., 2008). Translocation of NFKB to the nucleus causes upregulation of both proinflammatory mediators and regulatory proteins (Bonizzi and Karin, 2004). The resulting collection of proinflammatory mediators, acting through different receptors and secondary messengers, reinforces the initial stimulus of LPS binding and activates related inflammatory branches.

\section{Detoxification and Clearance of LPS}

Once in the body, the fate of LPS depends on its localization. In blood, LPS can be detoxified through the following 4 mechanisms: (1) sequestration by binding proteins, (2) enzymatic alteration of lipid A, (3) uptake and catabolism by macrophages, particularly Kupffer cells of the liver, and (4) modification of cellular responses to a more tolerant state (Hampton and Raetz, 1991; Munford, 2005). In the mammary gland, LPS can be detoxified, cross the blood-milk barrier to enter systemic circulation, or be removed through milking.
Ziv et al. (1976) showed that after administering a high dose of LPS (10 mg into each of 2 quarters), concentrations of LPS in milk from challenged glands began to fall within $1 \mathrm{~h}$, yet remained detectable after $48 \mathrm{~h}$; in comparison, blood remained negative or contained only trace amounts of LPS, matching the negligible concentrations in milk from the noninfused glands. A later study reported that experimental E. coli mastitis induced significant but sporadic increases in plasma LPS in only 3 out of 12 treated cows (Dosogne et al., 2002). This indicates that LPS is either detoxified within the mammary gland, rapidly detoxified upon entering circulation, or both. Therefore, LPS induces local effects but may not have direct systemic effects given its limited diffusion into the blood. Rather, the mediators released in response to LPS may play a central role in regulating galactopoiesis in the unchallenged mammary glands.

\section{ALTERED MAMMARY PHYSIOLOGY DURING LPS-MEDIATED MASTITIS}

Severe cases of mastitis induced by LPS infusion or E. coli infection are characterized by systemic, clinical signs of disease. Fever, elevated heart rate, lethargy, reduced feed intake, and hypersalivation can develop within hours of an LPS challenge and persist for several additional hours (Jacobsen et al., 2005; Aditya et al., 2017). Physiological responses to LPS are accompanied by pathophysiological changes in blood, wherein concentrations of cells and molecules may increase (e.g., immature band neutrophils, cytokines, eicosanoids, acute phase proteins), decrease (e.g., PMN), or exhibit variable responses (e.g., glucose; Lohuis et al., 1988; Mehrzad et al., 2001; Aitken et al., 2011). Therefore, early studies compared spatiotemporal changes in milk against blood components and clinical symptoms to establish relationships.

\section{Manifestation of Local and Systemic Effects in Milk}

The local response of a mammary gland to an intramammary bolus infusion of $E$. coli or LPS is welldocumented. The earliest changes reflect a change in the permeability of the blood-milk barrier, wherein concentrations of ions and albumin increase in milk, followed closely by migration of immune cells into the alveolar lumens (Lengemann and Pitzrick, 1986; Mehrzad et al., 2001; Wellnitz et al., 2015). Merely 12 h after administration, challenge quarters secrete milk with at least 50 times the concentration of somatic cells as pre-challenge; by $24 \mathrm{~h}$, milk yields of challenged quarters are reduced by 30 to $75 \%$ (Hoeben et al., 2000; Mehrzad et al., 2001; Petzl et al., 2008). In comparison, 
the response of noninflamed neighboring glands is less drastic, with comparatively smaller drops in milk yield, slight to negligible increases in SCC, and no changes in blood-milk barrier permeability.

Expanding upon earlier studies reviewed by Lohuis et al. (1988), a series of experiments led by Shuster in Harmon's laboratory demonstrated that noninflamed neighboring glands undergo hypogalactia during LPS-induced mastitis. At $12 \mathrm{~h}$ postinfusion, quarter milk yields declined approximately $20 \%$ in both LPSchallenged and neighboring saline-infused glands, after which 24-h yields recovered slightly in neighboring glands but continued to fall in LPS-challenged glands to $67 \%$ of pre-infusion yields (Shuster et al., 1991c). Further, markers of inflammation (e.g., SCC, albumin, lactoferrin) were increased only in milk from LPSchallenged glands. To account for these changes, the authors proposed that milk production in all glands was affected by "systemic suppression," with an additional "local suppression" related to inflammation only in LPS-challenged glands (Shuster et al., 1991c). However, these researchers recognized the dynamic nature of inflammatory responses within the first $12 \mathrm{~h}$ of an LPS challenge. Thus, they conducted a second experiment to better characterize the temporal response in milk production to an LPS challenge by increasing milkings from 2 to 4 times daily (Shuster et al., 1991a). Milk yields of treated and neighboring quarters were not affected at $6 \mathrm{~h}$ postchallenge, but both declined to a similar degree by $12 \mathrm{~h}$; milk component yields declined as well. Notably, milk fat yields were already lower at $6 \mathrm{~h}$, well before changes in other components, indicating differential regulation of milk components (Shuster et al., 1991a). Interestingly, changes in milk component concentrations from our recent experiment supported this suggestion. Both LPS-challenged and neighboring glands in the challenged cows failed to exhibit the early, transient increase in milk fat percentage observed in the mammary glands of control cows after milking. Further, all mammary glands in challenged cows produced less milk with lower lactose percentages relative to the control cows (Shangraw et al., 2020). These results clearly showed that, for these variables, responses of neighboring glands were strikingly similar to LPS-challenged glands, rather than to control glands, and different components were differentially regulated. Finally, having established a more precise timeline, Shuster's third experiment focused specifically on the systemic induction of inflammation by measuring milk production in response to an i.v. bolus infusion of LPS (Shuster et al., 1991b). Similar to the preceding experiments, milk yields declined by $33 \%$ by $12 \mathrm{~h}$ postinfusion. Most importantly, there was no indication of an immune response in milk (Shuster et al., 1991b). Therefore, further experiments focused on identifying the systemic mediators of hypogalactia.

Of the various systemic factors that could play a role in mediating hypogalactia in all quarters, Shuster and colleagues decided to investigate cytokines and glucocorticoids (Shuster and Harmon, 1992; Shuster et al., 1993). Interestingly, both regulate glucose metabolism. In lactating cows, the mammary gland requires plasmaderived glucose for lactose synthesis. Bovine MEC lack the necessary enzyme, glucose-6-phosphatase, to perform intracellular gluconeogenesis (Scott et al., 1976). Given this limitation, lactose yields depend upon the amount of glucose supplied to the mammary gland and the utilization of glucose by MEC. Some researchers have proposed that reduced milk yields result from lower glucose availability because cows with mastitis are often hypoglycemic (Lohuis et al., 1988; Waldron et al., 2003). Indeed, we reported a transient decrease in plasma glucose concentrations in challenged cows, which preceded the significant drop in milk yield at $24 \mathrm{~h}$ (Shangraw et al., 2020). Moreover, an activated immune system was estimated to utilize over $1 \mathrm{~kg}$ of glucose in the first $12 \mathrm{~h}$ following an i.v. infusion of LPS (Kvidera et al., 2017), which should theoretically limit the supply reaching the mammary gland. However, Kvidera et al. (2017) also reported that maintaining euglycemia during the LPS challenge did not prevent hypogalactia. Thus, glucose utilization by MEC may be directly regulated by systemic factors released during clinical mastitis whether or not glucose availability is limiting.

\section{Timing and Mechanisms of Putative Systemic Factors}

Cytokines. In blood, proinflammatory cytokines are among the earliest indicators of an inflammatory response. Plasma tumor necrosis factor- $\alpha$ (TNF- $\alpha$ ) increases within $1 \mathrm{~h}$ of infusion of LPS (Paape et al., 2002; Waldron et al., 2003), which is earlier than any cytokines have been reported to appear in milk. Tumor necrosis factor- $\alpha$ and IL- 8 also increased in the mammary lymph $2 \mathrm{~h}$ after an LPS challenge (Persson Waller et al., 2003). In healthy cows, subcutaneous injections of recombinant bovine TNF- $\alpha$ caused a $16 \%$ reduction in milk yield, increased plasma IL-1 $\beta$ concentrations, and altered the response of growth hormone, thyroid hormones, and cortisol to their stimulating hormones (Kushibiki et al., 2006). Given this association between cytokines and milk production, researchers subsequently examined whether cytokines could potentially mediate hypogalactia through control of lactose synthesis, either by dysregulation of glucose transporters or by interfering with mammary utilization of glucose. 
Facilitative glucose transporters, particularly SLC2A1 (insulin-independent GLUT1), are highly expressed in mammary tissue during lactation (Komatsu et al., 2005; Zhao 2014). Treatment of cultured murine MEC with TNF- $\alpha$ and IL-1 $\beta$ can induce internalization and degradation of GLUT1 from the basolateral membrane (Kobayashi et al., 2016; Matsunaga et al., 2018), limiting glucose uptake. On the other hand, because mammary glucose transport is mainly facilitative, glucose must be converted into a product, such as lactose, to maintain a downward concentration gradient into the cell. Conversion of glucose and galactose to lactose requires both subunits of lactose synthase as follows: B4GALT1 (31,4-galactosyltransferase 1) and LALBA $(\alpha-\mathrm{LA})$. In addition to GLUT1, TNF- $\alpha$ treatment of cultured murine MEC also reduced transcript expression of LALBA (Kobayashi et al., 2016). Similarly, bovine mammary tissue after intramammary LPS challenges showed negative regulation of $L A L B A$ (Schmitz et al., 2004; Gross et al., 2015). This appears to be a direct inhibition of $L A L B A$ due to inflammation, rather than reduced glucose availability, because altering the concentration of glucose affected expression of B4GALT1 but not LALBA in bovine MEC (Lin et al., 2016). Ultimately, it remains unclear whether lactose production is reduced in vivo by cytokines induced by LPS and, if so, whether the mechanism regulates the transport or utilization of glucose (or both).

Glucocorticoids. In cows administered with an i.v. bolus of LPS, plasma cortisol increases within 1 to $2 \mathrm{~h}$, peaks by 3 to $4 \mathrm{~h}$, then returns to baseline within 24 $\mathrm{h}$ postchallenge (Waldron et al., 2003; Vernay et al., 2012). A similar response in cortisol concentrations is observed after intramammary administration of LPS (Shuster et al., 1993; Waldron et al., 2006). Notably, treatment of cows with the potent synthetic glucocorticoid, dexamethasone, or supraphysiological doses of ACTH (adrenocorticotropic hormone) decreases milk yield (van der Kolk, 1990; Shamay et al., 2000). As noted above for cytokines, Hartmann and Kronfeld (1973) determined that dexamethasone affected milk production because the mammary gland utilized less glucose. It must be noted, however, that physiological doses of $\mathrm{ACTH}$ that induce a spike in plasma cortisol comparable to those observed during LPS challenges do not affect milk yield (van der Kolk et al., 1991; Shuster and Harmon, 1992). Thus, if cortisol is involved in the systemic control of milk production, it is likely in conjunction with other factors.

In searching for the systemic factors that regulate milk production during mastitis, results are equivocal. The most promising mediators of hypogalactia in neighboring quarters are proinflammatory cytokines, yet the underlying mechanisms regulating lactose synthesis remain unclear. Additionally, most studies have largely ignored changes in other milk components, particularly milk fat. Future studies must continue to investigate the effects of these and novel factors on lactating mammary tissue to understand the regulation of lactation in all mammary glands in response to mastitis.

\section{TRANSCRIPTOMICS TO IDENTIFY SYSTEMIC FACTORS AFFECTING LACTATION}

Due to the diversity of factors potentially involved in the local and systemic regulation of mammary physiology, research has recently turned to global approaches to identify targets of interest and mechanistic relationships. Microarrays and RNA sequencing are powerful tools to assess global gene expression and answer complex biological questions. Unsurprisingly, the main focus of transcriptomic studies on mastitis has been to unravel the immune response, as reviewed by Rinaldi et al. (2010b). Most studies have emphasized the kinetics of the immune response to different mediators, such as LPS, E. coli, or S. aureus, to better understand the host response (Table 1). With few exceptions, glands with acute mastitis show an increased expression of immune-responsive and proinflammatory genes. From a phenotypic standpoint, this matches the local response observed in milk. What differs between different mediators are the kinetics of the immune response and the specific genes that are altered. For example, studies in which mammary glands were infused with LPS identified differential expression of genes for cytokines, chemokines, and acute phase proteins hours earlier than studies in which glands were infused with E. coli (Zheng et al., 2006; Mitterhuemer et al., 2010; Buitenhuis et al., 2011). Fewer genes were differentially expressed in response to $S$. aureus than to $E$. coli in primary bovine MEC (Günther et al., 2011), matching the severity of responses in milk yield. Moreover, even within an inflamed gland, different regions of the mammary gland responded differently over time, with expression of proinflammatory genes appearing first in teat tissues and later in distal parenchyma (Rinaldi et al., 2010a; Petzl et al., 2016). Thus, the local transcriptional response to a pathogen can be distinct but at the same time induce common inflammatory pathways.

Several studies looked beyond the local responses within the inflamed mammary gland to investigate systemic effects, including changes in the liver during experimental mastitis (Minuti et al., 2015; Moyes et al., 2016). Similar to mammary tissue, inflammatory and immune responses were the earliest pathways affected in liver. Further, the expression patterns of genes 
Table 1. Summary of global transcriptomic studies on mammary tissue after experimental mastitis challenge

\begin{tabular}{|c|c|c|c|c|c|c|}
\hline Source & Species & Challenge type & RNA source ${ }^{1}$ & Timing, ${ }^{2} \mathrm{~h}$ & \multicolumn{2}{|c|}{ Control quarter ${ }^{3}$} \\
\hline Brenaut et al., 2012 & Goat & $\begin{array}{l}\text { Staphylococcus } \\
\text { aureus }\end{array}$ & MFG & $6,12,18,24,30$ & $\mathrm{Y}$ & $\mathrm{N}$ \\
\hline Brenaut et al., 2014 & Goat & S. aureus & MFG & $6,12,18,24,30$ & $\mathrm{Y}$ & $\mathrm{N}$ \\
\hline Buitenhuis et al., 2011 & Cow & Escherichia coli & Biopsy & 24,192 & $\mathrm{Y}$ & $\mathrm{N}$ \\
\hline Günther et al., 2011 & Cow & E. coli and S. aureus & pbMEC & $1,3,6,24$ & - & - \\
\hline Moyes et al., 2016 & Cow & E. coli & Biopsy & 24 & $\mathrm{Y}$ & $\mathrm{N}$ \\
\hline Rinaldi et al., 2010a & Cow & E. coli & MAP and teat & 12,24 & $\mathrm{Y}$ & $\mathrm{N}$ \\
\hline Shangraw et al., 2021 & Cow & LPS & Biopsy & 3,12 & $\mathrm{Y}$ & $\mathrm{Y}$ \\
\hline Zheng et al., 2006 & Mouse & LPS & MAP & 4 & $\mathrm{Y}$ & $\mathrm{N}$ \\
\hline
\end{tabular}

$\overline{{ }^{1} \mathrm{MAP}}=$ mammary alveolar parenchyma; MFG $=$ milk fat globules; pbMEC $=$ primary bovine mammary epithelial cells, Biopsy $=$ mammary biopsy.

${ }^{2}$ Time of mammary sample collection after intramammary challenge.

${ }^{3}$ Control quarter represents samples collected from unchallenged quarters in the challenged animal (internal) or from a healthy animal (external). $\mathrm{Y}=$ yes; $\mathrm{N}=$ no.

encoding acute phase proteins and metabolic enzymes confirmed previous evidence of elevated concentrations of acute phase proteins and altered hepatic metabolism during mastitis (Lohuis et al., 1988; Waldron et al., 2003).

For the liver to respond to a distant, localized source of inflammation, it is logical to assume that other organs may respond as well. In reviewing the literature, however, few transcriptomic studies on mastitis have been designed to assess systemic changes in the noninflamed neighboring glands, either by comparison against a pre-challenge sample or to a separate, healthy animal. Out of 9 in vivo transcriptomic studies, only one by Mitterhuemer et al. (2010) used an appropriate design to quantify changes in neighboring glands, and none compared responses against a pre-challenge sample from the same animal (Table 1). To assess a local inflammatory response, it is valid to compare a challenged quarter against an unchallenged, healthy quarter from the same animal; the popularity of this comparison is reflected in the typical design for these studies (Table 1). The issue with this comparison arises when attempting to determine underlying mechanisms of systemic responses, including hypogalactia, without an appropriate control for neighboring samples.

Recognizing the need to understand the kinetics of LPS effects on gene expression, Schmitz et al. (2004) used a biopsy technique for frequent sampling of mammary tissue. One rear quarter was infused with $100 \mu \mathrm{g}$ of LPS, whereas the contralateral gland was infused with saline. Biopsies were collected every $3 \mathrm{~h}$, starting just before infusions, to measure gene expression relative to $0 \mathrm{~h}$ in both treated and neighboring control quarters. Using quantitative PCR, the authors confirmed a local immune response in LPS-challenged glands by the upregulation of inflammatory mediators (TNFA and COX2) at $3 \mathrm{~h}$ postchallenge. Further, genes specific to lactation ( $L A L B A$ and $C S N 3$ ) were significantly downregulated by $9 \mathrm{~h}$ in the challenged glands. Interestingly, when the authors analyzed the adjacent control quarters, minor but similar changes in TNFA and $L A L B A$ expression were apparent, indicating some systemic effects of the immune response on lactation (Schmitz et al., 2004). However, a limitation of this study was the lack of a synchronous negative control, which meant that all changes in gene expression over time were potentially confounded with biopsy-induced inflammation. Additionally, the response in milk from sampled quarters could not be measured over time due to blood contamination caused by biopsies.

A later study by Mitterhuemer et al. (2010) used a different approach to determine the systemic effect of $E$. coli mastitis on neighboring glands. In 2 groups of healthy cows, a single quarter was infused with $E$. coli. After 6 or $24 \mathrm{~h}$, cows were killed to collect mammary tissue from the $E$. coli-challenged and neighboring glands. A third group of cows was maintained under the same conditions but received infusions of saline to allow collection of healthy control tissue. By comparing tissue from cows with mastitis against healthy tissue, the authors not only identified the expected local inflammatory response to an E. coli infection but also 476 differentially expressed genes in the neighboring glands, of which 294 were identified in both quarters. Crucially, these common, systemically-regulated genes were associated with a protective immune response and with the negative regulation of lactation (Mitterhuemer et al., 2010). Moreover, the unique experimental design al- 
lowed milk to be collected before tissue harvest, unlike in the design used by Schmitz et al. (2004), allowing actual decreases in milk yields from both challenged and neighboring glands to be related to changes in gene expression.

A third study, by Jensen et al. (2013), supported the influence of systemic mediators of inflammation on noninflamed, neighboring quarters but failed to identify a local immune response. In this experiment, cows were administered 3 intramammary infusions, one each in the right front, right hind, and left hind quarters, at 3 time points over $24 \mathrm{~h}$, leaving the final quarter as an uninfected control. Cows received either E. coli or $S$. aureus infusions for comparison of the inflammatory response to each pathogen. However, the small number of differentially expressed genes in challenged quarters compared with the within-animal control, especially for $S$. aureus infections, led the authors to run post hoc analyses on the different control quarters. In doing so, they found 187 differentially expressed genes in control quarters, suggesting that gene expression was not stable but differed depending on the type of infection in challenged glands (Jensen et al., 2013). Further, over $25 \%$ of the genes identified in the E. coli control glands were also systemically regulated in the study by Mitterhuemer et al. (2010), indicating that these are common responses to systemic mediators of inflammation in neighboring glands.

To address this systemic regulation of milk production, our recent experiment was designed to analyze the transcriptomes of glands neighboring LPS-challenged glands. Similar to previous studies, we found that milk yields declined significantly in both the challenged and neighboring glands (Shangraw et al., 2020) but over $95 \%$ of the differentially regulated genes were only different in the challenged glands (Shangraw et al., 2021). However, increased expression of anti-inflammatory (TNFAIP3, NFKBIA) and glucocorticoid responsive $(F K B P 5, Z B T B 16)$ genes in neighboring glands suggested that these glands are affected by cytokines and glucocorticoids. Further, our data support the hypothesis that the release of systemic mediators of inflammation, rather than an influx of somatic cells, is the primary factor driving reduced milk production in clinically healthy mammary glands neighboring inflamed glands (Shangraw et al., 2021). Nevertheless, the specific causative mechanisms must still be determined.

The slow transition in transcriptomic studies from an exclusive focus on local inflammation to more subtle systemic responses is a natural progression as more powerful techniques become available and new studies build upon previous findings. Having reliable annotations to compare against allows researchers to validate new models and pursue novel findings. Indeed, recent studies by Brenaut et al. (2012, 2014) suggest that isolation of RNA from milk fat provides a noninvasive method for frequently sampling the MEC transcriptome. Compared against RNA from whole mammary tissue, RNA from milk fat had lower contamination from immune cells but similar expression of genes required for milk synthesis (Brenaut et al., 2012). In response to $S$. aureus infection, immune-responsive genes were mainly upregulated (Brenaut et al., 2014), indicating a direct immune response by MEC as previously found in cultured MEC (Günther et al., 2011). On top of this transcriptional validation, the noninvasive aspect is intriguing both as a method to improve understanding of kinetic and spatial changes to MEC in vivo and to simultaneously collect milk production data for biological validation.

Overall, each transcriptomic study has brought a different aspect to the regulation of the mammary gland. The majority of studies have advanced our understanding of the local mammary response to inflammation, and it is important to continue such investigations into the response of neighboring glands to systemic mediators of inflammation. The marked decline in milk yield of mammary glands neighboring clinically inflamed glands strongly implies that other systemic sources of inflammation, such as endometritis, subacute ruminal acidosis, respiratory disease, or lameness could also affect milk yield and mammary gene expression.

\section{CONCLUSIONS}

Our understanding of the regulation of lactation during mastitis has progressed over the past century with advancements in technology, from clinical observations to biochemical analyses to transcriptomics. Each study has built upon previous findings, yet the factor or factors causing transient hypogalactia in noninflamed mammary quarters neighboring mammary glands with clinical mastitis remain elusive. Observational and hypothesis-driven studies provided the first evidence that neighboring glands could also be affected during a localized case of clinical mastitis. As connections between potential mediators and responses grew, targeted studies of cytokines and glucocorticoids provided incomplete clues to explain how hypogalactia occurs during mastitis. Most recently, a few global transcriptomic studies have highlighted the changes that occur in noninflamed quarters, potentially pointing to the key factors regulating lactation. By focusing on systemic factors, we may unlock the causative mechanisms regulating lactation during clinical mastitis and other episodes of acute inflammation, allowing for improvements in milk production and animal welfare. 


\section{ACKNOWLEDGMENTS}

Erin Shangraw was supported by an F. B. Miller Fellowship through the Division of Animal Sciences, University of Missouri. The authors have not stated any conflicts of interest.

\section{REFERENCES}

Aditya, S., E. Humer, P. Pourazad, R. Khiaosa-Ard, J. Huber, and Q. Zebeli. 2017. Intramammary infusion of Escherichia coli lipopolysaccharide negatively affects feed intake, chewing, and clinical variables, but some effects are stronger in cows experiencing subacute rumen acidosis. J. Dairy Sci. 100:1363-1377. https://doi .org/10.3168/jds.2016-11796.

Aghamohammadi, M., D. Haine, D. F. Kelton, H. W. Barkema, H. Hogeveen, G. P. Keefe, and S. Dufour. 2018. Herd-level mastitisassociated costs on Canadian dairy farms. Front. Vet. Sci. 5:100. https://doi.org/10.3389/fvets.2018.00100.

Aitken, S. L., C. M. Corl, and L. M. Sordillo. 2011. Immunopathology of mastitis: Insights into disease recognition and resolution. J. Mammary Gland Biol. Neoplasia 16:291-304. https://doi.org/10 .1007/s10911-011-9230-4.

Akers, R. M. 2002. Endocrine, growth factor, and neural regulation of mammary function. Page 172 in Lactation and the Mammary Gland. Iowa State Press.

Bannerman, D. D. 2009. Pathogen-dependent induction of cytokines and other soluble inflammatory mediators during intramammary infection of dairy cows. J. Anim. Sci. 87(suppl_13):10-25. https:/ /doi.org/10.2527/jas.2008-1187.

Bonizzi, G., and M. Karin. 2004. The two NF-кB activation pathways and their role in innate and adaptive immunity. Trends Immunol. 25:280-288. https://doi.org/10.1016/j.it.2004.03.008.

Brenaut, P., R. Bangera, C. Bevilacqua, E. Rebours, C. Cebo, and P. Martin. 2012. Validation of RNA isolated from milk fat globules to profile mammary epithelial cell expression during lactation and transcriptional response to a bacterial infection. J. Dairy Sci. 95:6130-6144. https://doi.org/10.3168/jds.2012-5604.

Brenaut, P., L. Lefèvre, A. Rau, D. Laloë, G. Pisoni, P. Moroni, C. Bevilacqua, and P. Martin. 2014. Contribution of mammary epithelial cells to the immune response during early stages of a bacterial infection to Staphylococcus aureus. Vet. Res. 45:16. https://doi .org/10.1186/1297-9716-45-16.

Buitenhuis, B., C. M. Røntved, S. M. Edwards, K. L. Ingvartsen, and P. Sørensen. 2011. In depth analysis of genes and pathways of the mammary gland involved in the pathogenesis of bovine Escherichia coli- mastitis. BMC Genomics 12:130. https://doi.org/10 .1186/1471-2164-12-130.

Burvenich, C., V. Van Merris, J. Mehrzad, A. Diez-Fraile, and L. Duchateau. 2003. Severity of E coli mastitis is mainly determined by cow factors. Vet. Res. 34:521-564. https://doi.org/10.1051/vetres: 2003023

Chen, Q., G. He, W. Zhang, T. Xu, H. Qi, J. Li, Y. Zhang, and M.-Q. Gao. 2016. Stromal fibroblasts derived from mammary gland of bovine with mastitis display inflammation-specific changes. Sci. Rep. 6:27462. https://doi.org/10.1038/srep27462.

Dosogne, H., E. Meyer, A. Sturk, J. van Loon, A. M. Massart-Leën, and C. Burvenich. 2002. Effect of enrofloxacin treatment on plasma endotoxin during bovine Escherichia coli mastitis. Inflamm. Res. 51:201-205. https://doi.org/10.1007/PL00000293.

Gröhn, Y. T., D. J. Wilson, R. N. González, J. A. Hertl, H. Schulte, G. Bennett, and Y. H. Schukken. 2004. Effect of pathogen-specific clinical mastitis on milk yield in dairy cows. J. Dairy Sci. 87:3358 3374. https://doi.org/10.3168/jds.S0022-0302(04)73472-4.

Gross, J. J., H. A. van Dorland, O. Wellnitz, and R. M. Bruckmaier. 2015. Glucose transport and milk secretion during manipulated plasma insulin and glucose concentrations and during LPSinduced mastitis in dairy cows. J. Anim. Physiol. Anim. Nutr. (Berl.) 99:747-756. https://doi.org/10.1111/jpn.12259.
Günther, J., K. Esch, N. Poschadel, W. Petzl, H. Zerbe, S. Mitterhuemer, H. Blum, and H.-M. Seyfert. 2011. Comparative kinetics of Escherichia coli- and Staphylococcus aureus-specific activation of key immune pathways in mammary epithelial cells demonstrates that $S$. aureus elicits a delayed response dominated by interleukin-6 (IL-6) but not by IL-1A or tumor necrosis factor alpha. Infect. Immun. 79:695-707. https://doi.org/10.1128/IAI.01071-10.

Hampton, R. Y., and C. R. Raetz. 1991. Macrophage catabolism of lipid A is regulated by endotoxin stimulation. J. Biol. Chem. 266:19499-19509. https://doi.org/10.1016/S0021-9258(18)55024 $-9$.

Hartmann, P. E., and D. S. Kronfeld. 1973. Mammary blood flow and glucose uptake in lactating cows given dexamethasone. J. Dairy Sci. 56:896-902. https://doi.org/10.3168/jds.S0022-0302(73)85274 -9 .

Hoeben, D., C. Burvenich, E. Trevisi, G. Bertoni, J. Hamann, R. Bruckmaier, and J. Blum. 2000. Role of endotoxin and TNF- $\alpha$ in the pathogenesis of experimentally induced coliform mastitis in periparturient cows. J. Dairy Res. 67:503-514. https://doi.org/10 .1017/S0022029900004489.

Hogeveen, H., W. Steeneveld, and C. A. Wolf. 2019. Production diseases reduce the efficiency of dairy production: A review of the results, methods, and approaches regarding the economics of mastitis. Annu. Rev. Resour. Econ. 11:289-312. https://doi.org/10 .1146/annurev-resource-100518-093954.

Hughes, K., J. A. Wickenden, J. E. Allen, and C. J. Watson. 2012. Conditional deletion of Stat3 in mammary epithelium impairs the acute phase response and modulates immune cell numbers during post-lactational regression. J. Pathol. 227:106-117. https://doi .org/10.1002/path.3961.

Ibeagha-Awemu, E. M., J.-W. Lee, A. E. Ibeagha, D. D. Bannerman, M. J. Paape, and X. Zhao. 2008. Bacterial lipopolysaccharide induces increased expression of toll-like receptor (TLR) 4 and downstream TLR signaling molecules in bovine mammary epithelial cells. Vet. Res. 39:11. https://doi.org/10.1051/vetres:2007047.

Jacobsen, S., T. Toelboell, and P. H. Andersen. 2005. Dose dependency and individual variability in selected clinical, haematological and blood biochemical responses after systemic lipopolysaccharide challenge in cattle. Vet. Res. 36:167-178. https://doi.org/10.1051/ vetres:2004062.

Jensen, K., J. Günther, R. Talbot, W. Petzl, H. Zerbe, H. J. Schuberth H. M. Seyfert, and E. J. Glass. 2013. Escherichia coli- and Staphylococcus aureus-induced mastitis differentially modulate transcriptional responses in neighbouring uninfected bovine mammary gland quarters. BMC Genomics 14:36. https://doi.org/10.1186/ 1471-2164-14-36.

Kobayashi, K., C. Kuki, S. Oyama, and H. Kumura. 2016. Pro-inflammatory cytokine TNF- $\alpha$ is a key inhibitory factor for lactose synthesis pathway in lactating mammary epithelial cells. Exp. Cell Res. 340:295-304. https://doi.org/10.1016/j.yexcr.2015.10.030.

Komatsu, T., F. Itoh, S. Kushibiki, and K. Hodate. 2005. Changes in gene expression of glucose transporters in lactating and nonlactating cows. J. Anim. Sci. 83:557-564. https://doi.org/10.2527/2005 $.833557 \mathrm{x}$.

Kushibiki, S., H. Shingu, T. Komatsu, F. Itoh, E. Kasuya, H. Aso, and K. Hodate. 2006. Effect of recombinant bovine tumor necrosis factor- $\alpha$ on hormone release in lactating cows. Anim. Sci. J. 77:603-612. https://doi.org/10.1111/j.1740-0929.2006.00392.x.

Kvidera, S. K., E. A. Horst, M. Abuajamieh, E. J. Mayorga, M. V. S. Fernandez, and L. H. Baumgard. 2017. Glucose requirements of an activated immune system in lactating Holstein cows. J. Dairy Sci 100:2360-2374. https://doi.org/10.3168/jds.2016-12001.

Lacasse, P., S. Ollier, V. Lollivier, and M. Boutinaud. 2016. New insights into the importance of prolactin in dairy ruminants. J. Dairy Sci. 99:864-874. https://doi.org/10.3168/jds.2015-10035.

Lengemann, F. W., and M. Pitzrick. 1986. Effects of endotoxin on mammary secretion of lactating cows. J. Dairy Sci. 69:1250-1258. https://doi.org/10.3168/jds.S0022-0302(86)80531-8.

Lin, Y., X. Sun, X. Hou, B. Qu, X. Gao, and Q. Li. 2016. Effects of glucose on lactose synthesis in mammary epithelial cells from 
dairy cow. BMC Vet. Res. 12:81. https://doi.org/10.1186/s12917 -016-0704-x.

Lohuis, J. A. C. M., J. H. M. Verheijden, C. Burvenich, and A. S. J. P. A. M. van Miert. 1988. Pathophysiological effects of endotoxins in ruminants. Vet. Q. 10:117-125. https://doi.org/10.1080/01652176 .1988 .9694158

Matsunaga, K., Y. Tsugami, A. Kumai, T. Suzuki, T. Nishimura, and K. Kobayashi. 2018. IL-1 $\beta$ directly inhibits milk lipid production in lactating mammary epithelial cells concurrently with enlargement of cytoplasmic lipid droplets. Exp. Cell Res. 370:365-372. https://doi.org/10.1016/j.yexcr.2018.06.038.

McCoard, S. A., A. A. Hayashi, Q. Sciascia, J. Rounce, B. Sinclair, W. C. McNabb, and N. C. Roy. 2016. Mammary transcriptome analysis of lactating dairy cows following administration of bovine growth hormone. Animal 10:2008-2017. https://doi.org/10.1017/ S1751731116000987.

Mehrzad, J., H. Dosogne, E. Meyer, and C. Burvenich. 2001. Local and systemic effects of endotoxin mastitis on the chemiluminescence of milk and blood neutrophils in dairy cows. Vet. Res. 32:131-144. https://doi.org/10.1051/vetres:2001100.

Merle, R., A. Schröder, and J. Hamann. 2007. Cell function in the bovine mammary gland: a preliminary study on interdependence of healthy and infected udder quarters. J. Dairy Res. 74:174-179. https://doi.org/10.1017/S002202990600238X.

Minuti, A., Z. Zhou, D. E. Graugnard, S. L. Rodriguez-Zas, A. R. Palladino, F. C. Cardoso, E. Trevisi, and J. J. Loor. 2015. Acute mammary and liver transcriptome responses after an intramammary Escherichia coli lipopolysaccharide challenge in postpartal dairy cows. Physiol. Rep. 3:e12388. https://doi.org/10.14814/phy2 .12388 .

Mitterhuemer, S., W. Petzl, S. Krebs, D. Mehne, A. Klanner, E. Wolf, H. Zerbe, and H. Blum. 2010. Escherichia coli infection induces distinct local and systemic transcriptome responses in the mammary gland. BMC Genomics 11:138. https://doi.org/10.1186/1471 $-2164-11-138$.

Moyes, K. M., P. Sørensen, and M. Bionaz. 2016. The impact of intramammary Escherichia coli challenge on liver and mammary transcriptome and cross-talk in dairy cows during early lactation using RNAseq. PLoS One 11:e0157480. https://doi.org/10.1371/journal .pone. 0157480 .

Munford, R. S. 2005. Invited review: Detoxifying endotoxin: Time, place and person. J. Endotoxin Res. 11:69-84. https://doi.org/10 $.1177 / 09680519050110020201$.

Paape, M. J., P. M. Rautiainen, E. M. Lilius, C. E. Malstrom, and T. H. Elsasser. 2002. Development of anti-bovine TNF- $\alpha \mathrm{mAb}$ and ELISA for quantitating TNF- $\alpha$ in milk after intramammary injection of endotoxin. J. Dairy Sci. 85:765-773. https://doi.org/ 10.3168/jds.S0022-0302(02)74134-9.

Persson Waller, K., I. G. Colditz, S. Lun, and K. Östensson. 2003. Cytokines in mammary lymph and milk during endotoxin-induced bovine mastitis. Res. Vet. Sci. 74:31-36. https://doi.org/10.1016/ S0034-5288(02)00147-9.

Petzl, W., J. Günther, K. Mühlbauer, H.-M. Seyfert, H.-J. Schuberth, J. Hussen, C. Sauter-Louis, A. Hafner-Marx, and H. Zerbe. 2016. Early transcriptional events in the udder and teat after intra-mammary Escherichia coli and Staphylococcus aureus challenge. Innate Immun. 22:294-304. https://doi.org/10.1177/1753425916640057.

Petzl, W., H. Zerbe, J. Günther, W. Yang, H.-M. Seyfert, G. Nürnberg, and H.-J. Schuberth. 2008. Escherichia coli, but not Staphylococcus aureus triggers an early increased expression of factors contributing to the innate immune defense in the udder of the cow. Vet. Res. 39:18.

Porcheray, F., S. Viaud, A.-C. Rimaniol, C. Léone, B. Samah, N Dereuddre-Bosquet, D. Dormont, and G. Gras. 2005. Macrophage activation switching: An asset for the resolution of inflammation. Clin. Exp. Immunol. 142:481-489. https://doi.org/10.1111/j.1365 $-2249.2005 .02934 . x$.

Rietschel, E. T., T. Kirikae, F. U. Schade, U. Mamat, G. Schmidt, H. Loppnow, A. J. Ulmer, U. Zähringer, U. Seydel, F. Di Padova, M. Schreier, and H. Brade. 1994. Bacterial endotoxin: Molecu- lar relationships of structure to activity and function. FASEB J. 8:217-225. https://doi.org/10.1096/fasebj.8.2.8119492.

Rinaldi, M., R. W. Li, D. D. Bannerman, K. M. Daniels, C. EvockClover, M. V. B. Silva, M. J. Paape, B. Van Ryssen, C. Burvenich, and A. V. Capuco. 2010a. A sentinel function for teat tissues in dairy cows: Dominant innate immune response elements define early response to E. coli mastitis. Funct. Integr. Genomics 10:2138. https://doi.org/10.1007/s10142-009-0133-z.

Rinaldi, M., R. W. Li, and A. V. Capuco. 2010b. Mastitis associated transcriptomic disruptions in cattle. Vet. Immunol. Immunopathol. 138:267-279. https://doi.org/10.1016/j.vetimm.2010.10.005.

Ryman, V. E., N. Packiriswamy, and L. M. Sordillo. 2015. Role of endothelial cells in bovine mammary gland health and disease. Anim. Health Res. Rev. 16:135-149. https://doi.org/10.1017/ S1466252315000158.

Schmitz, S., M. W. Pfaffl, H. H. D. Meyer, and R. M. Bruckmaier. 2004. Short-term changes of mRNA expression of various inflammatory factors and milk proteins in mammary tissue during LPSinduced mastitis. Domest. Anim. Endocrinol. 26:111-126. https:// doi.org/10.1016/j.domaniend.2003.09.003.

Schwarz, D., U. S. Diesterbeck, S. König, K. Brügemann, K. Schlez, M. Zschöck, W. Wolter, and C.-P. Czerny. 2011. Flow cytometric differential cell counts in milk for the evaluation of inflammatory reactions in clinically healthy and subclinically infected bovine mammary glands. J. Dairy Sci. 94:5033-5044. https://doi.org/10 $.3168 /$ jds.2011-4348.

Scott, R. A., D. E. Bauman, and J. H. Clark. 1976. Cellular gluconeogenesis by lactating bovine mammary tissue. J. Dairy Sci. 59:50-56. https://doi.org/10.3168/jds.S0022-0302(76)84155-0.

Shamay, A., F. Shapiro, H. Barash, I. Bruckental, and N. Silanikove. 2000. Effect of dexamethasone on milk yield and composition in dairy cows. Ann. Zootech. 49:343-352. https://doi.org/10.1051/ animres:2000125.

Shangraw, E. M., R. O. Rodrigues, R. K. Choudhary, F.-Q. Zhao, and T. B. McFadden. 2021. Hypogalactia in mammary quarters adjacent to lipopolysaccharide-infused quarters is associated with transcriptional changes in immune genes. J. Dairy Sci. 104:9276-9286. https://doi.org/10.3168/jds.2020-20048.

Shangraw, E. M., R. O. Rodrigues, M. C. Witzke, R. K. Choudhary, F.-Q. Zhao, and T. B. McFadden. 2020. Intramammary lipopolysaccharide infusion induces local and systemic effects on milk components in lactating bovine mammary glands. J. Dairy Sci. 103:7487-7497. https://doi.org/10.3168/jds.2019-18022.

Shuster, D. E., and R. J. Harmon. 1992. High cortisol concentrations and mediation of the hypogalactia during endotoxin-induced mastitis. J. Dairy Sci. 75:739-746. https://doi.org/10.3168/jds.S0022 -0302(92)77811-4.

Shuster, D. E., R. J. Harmon, J. A. Jackson, and R. W. Hemken. 1991a. Endotoxin mastitis in cows milked four times daily. J. Dairy Sci. 74:1527-1538. https://doi.org/10.3168/jds.S0022 -0302(91)78313-6.

Shuster, D. E., R. J. Harmon, J. A. Jackson, and R. W. Hemken. 1991b. Reduced lactational performance following intravenous endotoxin administration to dairy cows. J. Dairy Sci. 74:3407-3411. https://doi.org/10.3168/jds.S0022-0302(91)78530-5.

Shuster, D. E., R. J. Harmon, J. A. Jackson, and R. W. Hemken. 1991c. Suppression of milk production during endotoxin-induced mastitis. J. Dairy Sci. 74:3763-3774. https://doi.org/10.3168/jds .S0022-0302(91)78568-8.

Shuster, D. E., M. E. Kehrli, and M. G. Stevens. 1993. Cytokine production during endotoxin induced mastitis in lactating dairy cows. Am. J. Vet. Res. 54:80-85.

Singh, K., K. M. Swanson, H. V. Henderson, R. A. Erdman, and K. Stelwagen. 2015. The effect of milking reinitiation following extended nonmilking periods on lactation in primiparous dairy cows. J. Dairy Sci. 98:7666-7674. https://doi.org/10.3168/jds.2014 $-8883$.

Stelwagen, K., V. C. Farr, and H. A. McFadden. 1999. Alteration of the sodium to potassium ratio in milk and the effect on milk secretion in goats. J. Dairy Sci. 82:52-59. https://doi.org/10.3168/jds .S0022-0302(99)75208-2. 
Stelwagen, K., and C. H. Knight. 1997. Effect of unilateral once or twice daily milking of cows on milk yield and udder characteristics in early and late lactation. J. Dairy Res. 64:487-494. https://doi .org/10.1017/S0022029997002458.

Turner, C. W. 1934. The functional individuality of the mammary glands of the udder of the dairy cow. Univ. Missouri Agric. Exp. Stn. Res. Bull. 211.

van der Kolk, J. H. 1990. The bovine pituitary-adrenocortical axis and milk yield. Vet. Q. 12:114-120. https://doi.org/10.1080/01652176 .1990 .9694253

van der Kolk, J. H., H. J. Breukink, T. Wensing, and J. A. Mol. 1991. Adrenocortical function testing in dairy cows and its effect on milk yield. Vet. Q. 13:144-147. https://doi.org/10.1080/01652176.1991 .9694299 .

Vernay, M. C. M. B., O. Wellnitz, L. Kreipe, H. A. van Dorland, and R. M. Bruckmaier. 2012. Local and systemic response to intramammary lipopolysaccharide challenge during long-term manipulated plasma glucose and insulin concentrations in dairy cows. J. Dairy Sci. 95:2540-2549. https://doi.org/10.3168/jds.2011-5188.

Verstrepen, L., T. Bekaert, T.-L. Chau, J. Tavernier, A. Chariot, and R. Beyaert. 2008. TLR-4, IL-1R and TNF-R signaling to NF- $\kappa$ B variations on a common theme. Cell. Mol. Life Sci. 65:2964-2978. https://doi.org/10.1007/s00018-008-8064-8.

Waldron, M. R., A. E. Kulick, A. W. Bell, and T. R. Overton. 2006. Acute experimental mastitis is not causal toward the development of energy-related metabolic disorders in early postpartum dairy cows. J. Dairy Sci. 89:596-610. https://doi.org/10.3168/jds.S0022 $-0302(06) 72123-3$.

Waldron, M. R., T. Nishida, B. J. Nonnecke, and T. R. Overton. 2003. Effect of lipopolysaccharide on indices of peripheral and hepatic metabolism in lactating cows. J. Dairy Sci. 86:3447-3459. https:// doi.org/10.3168/jds.S0022-0302(03)73949-6.

Wall, E. H., and T. B. McFadden. 2007. The milk yield response to frequent milking in early lactation of dairy cows is locally regulated. J. Dairy Sci. 90:716-720. https://doi.org/10.3168/jds.S0022 $-0302(07) 71555-2$.

Wellnitz, O., C. Zbinden, J. Lüttgenau, H. Bollwein, and R. M. Bruckmaier. 2015. Different chronological patterns of appearance of blood derived milk components during mastitis indicate different mechanisms of transfer from blood into milk. J. Dairy Res. 82:322327. https://doi.org/10.1017/S0022029915000345.

Zhao, F.-Q. 2014. Biology of glucose transport in the mammary gland. J. Mammary Gland Biol. Neoplasia 19:3-17. https://doi.org/10 .1007/s10911-013-9310-8.

Zheng, J., A. D. Watson, and D. E. Kerr. 2006. Genome-wide expression analysis of lipopolysaccharide-induced mastitis in a mouse model. Infect. Immun. 74:1907-1915. https://doi.org/10.1128/IAI .74.3.1907-1915.2006.

Ziv, G., I. Hartman, E. Bogin, J. Abidar, and A. Saran. 1976. Endotoxin in blood and milk and enzymes in the milk of cows during experimental Escherichia coli endotoxin mastitis. Theriogenology 6:343-352. https://doi.org/10.1016/0093-691X(76)90026-1.

\section{ORCIDS}

E. M. Shangraw ำ https://orcid.org/0000-0001-8761-1549

T. B. McFadden (ํ) https://orcid.org/0000-0001-5101-6844 